\title{
"Speak What We Feel, Not What We Ought to Say": Moral Distress and Bioethics
}

\author{
Leigh E. Rich • Michael A. Ashby
}

Received: 5 June 2013 / Accepted: 11 June 2013

(C) Springer Science+Business Media Dordrecht 2013

At the tragic end of Shakespeare's King Lear, Edgar, the son of the Earl of Gloucester, clearly sides with the emotions as he laments the state of the king and his kingdom: "The weight of this sad time we must obey,/Speak what we feel, not what we ought to say" (V.iii.323-324). ${ }^{1}$ Although long debated by Shakespeare scholars, these last lines, according to Russell A. Peck, illustrate Edgar's passage from a naïve and egocentric

\footnotetext{
${ }^{1}$ These are credited to Edgar in the folio (1623) version of the play but Albany in the quarto (1608). Much has been written about the differences between the versions and, particularly, attribution and meaning of the final four lines. Peck, however, notes in a footnote: "The 'bad quarto' gives the last speech of the play to Albany. It seems to me that those editors who follow the folio (which is the accepted copytext for the play) and give the final speech to Edgar have the stronger case" $(1967,232)$. We follow Peck's lead and his interpretation of Edgar's character here, as this provides insight into the experience of and means for resolving moral distress, which is the theme of this editorial and the symposium in this issue of the Journal of Bioethical Inquiry.
}

\section{E. Rich $(\bowtie)$}

Department of Health Sciences (Public Health), Armstrong Atlantic State University, 11935 Abercorn Street,

Solms 201, Savannah, GA 31419, USA

e-mail: leigh.rich@armstrong.edu

M. A. Ashby

Palliative Care Service, Royal Hobart Hospital, Southern Tasmania Area Health Service, and School of Medicine, Faculty of Health Sciences, University of Tasmania, 1st Floor, Peacock Building, Repatriation Centre, 90 Davey Street, Hobart, TAS 7000, Australia e-mail: michael.ashby@dhhs.tas.gov.au though dutiful son, who is deceived by his brother and disinherited and exiled by his father, to that of "a good man" (1967, 235) and even "a kind of universal son" (1967, 230), who "learns to see beyond himself" (1967, 224) and "empathize with and take upon himself the afflictions of his fellow men" $(1967,226)$. "Through his trials," Peck notes, "Edgar attains maturity and even gains a kind of authority" $(1967,234)$ - but an authority beyond merely that of victor on the side of justice. Rather, he is painted as a philosopher, whose examined life (as Socrates would have it) through the donning of various disguises and identities enables him (and us) to answer "the most oft asked question in the play: "What are you?"” (Peck 1967, 231).

Moral philosophers, of course, when reading this line outside of the context of the play surely would think Edgar has it backwards: that one "ought" to say (or do) what is morally required, not whatever fits best one's inclinations. The "ought" in "not what we ought to say" as used by Edgar and Shakespeare, however, refers to the desires of others, particularly those in various positions of power that can bestow upon us pleasure or pain. And in phrasing the concept of "doing what is morally required" in this way - that is, in terms of "[s]peak[ing] what we feel, not what we ought to say," Edgar and Shakespeare re-elevate that "unruly emotion," long discredited as the disruptive and dark forces of "passion" and "Unreason" (Held and Lloyd cited in Held 2002, 54), and thus illuminate its role and essential value in the good.

Peck translates Edgar's and King Lear's final lines in this way: "Behold and feel: that is all we may conclude. 
Yet perhaps that is the highest tribute one man living in this world may pay another. That is the end at which the pilgrim Edgar arrives" (1967, 237).

Embedded in Edgar's final speech and indeed throughout his philosophical searching in the play is a laying bare of the Western Enlightenment struggle pitting left brain against right, reason against intuition, positivism against holism. When Edgar emboldens us to "[s]peak what we feel, not what we ought to say" - what Peck deems "perhaps the most penetrating remark in the play" $(1967,232-233)$ - it is a call to collapsing a dichotomy that leaves room for and at times even fosters insincerity and immorality: "If men speak what they 'ought to say' (and they do), then we have Gonerils, Regans, Oswalds, and Edmunds. And we have Lears who would flatter themselves by disguising, demanding, and measuring love in terms of calculated conceits" (Peck 1967, 233). Surely such a divided and uneven system hinders the very process of discerning the right course of action in life. (Indeed literal and structural wars in terms of race, gender, and other identities have been constructed on this perceived distinction.)

For how is one to recognize and rectify wrong choices or iniquitous conditions if our ability to sense the stirrings of moral concern has, like Edgar, been condemned and cast out of (to borrow from Kant) the kingdom of ends?

Even more troubling, what happens when the right action cannot be realized? Can reason alone unlock shackles and "mind-forg'd manacles" (as William Blake phrased it), or need passion play a part?

It is telling that the concept of "moral distress" in bioethics was reared by scholars working in nursing and feminist ethics, fields often relegated to lesser status in traditional health care and academic hierarchies and, thus, vantage points at the margins (see Jameton 2013). This distance, however, as King Lear illustrates, can provide an understanding of both the forest and the trees. That said, in morally difficult situations, discrepancies in power or other resources may leave those who are able "to see beyond himself" (or herself) in a state of suffering or, like Edgar, with a "sense of nothingness thrust upon him in one fell swoop" (Peck 1967, 224). Moral distress, given a new life and brought to the fore by philosopher Andrew Jameton in the 1980s, arises when "one knows the right thing to do, but institutional constraints make it nearly impossible to pursue the right course of action" (Jameton 1984, 6). Elizabeth Peter and Joan Liaschenko (2013), in this issue of the Journal of
Bioethical Inquiry $(J B I)$, begin from a slightly broader perspective, citing Joan McCarthy and Rick Deady's approach to moral distress as "an umbrella concept that captures the range of experiences of individuals who are morally constrained" $(2008,254){ }^{2}$

Those who work in care settings, attending to the essential needs of human beings to attain lives of "complete physical, mental and social well-being" (World Health Organization 1946, 2), run up against examples of such constraints all too often. In everyday hospital practice, the first portal of ethical deliberation is commonly a concern raised by nursing staff regarding the care of patients. A sense of moral outrage is a frequent qualitative dimension of this expression. We also know, as highlighted in several papers in this issue of the $J B I$ as well as elsewhere, that for many nurses the channels to express these concerns are poorly developed or nonexistent (see, e.g., Edwards, McClement, and Read 2013). Much of this goes "underground" and/or is internalized by nurses, and this in itself presumably has largely unquantified negative impacts on professional lives, leading to compassion exhaustion, burnout, and job dissatisfaction.

For example, care-taking and decision-making at the end of life are frequent triggers of moral distress for nurses, especially those who work in acute hospitals. The treatment of dying people as if they are curable - what the French call "therapeutic harassment"-is often distressing to nurses because they are witness to the patient's suffering, the patient's true condition, and the lack of realitybased and emotive honesty in this highly analytical and medicalized setting. And all of this is cloaked in a still male-orientated professional medical culture, with its incongruities of power and gender and modes of "seeing" that view treatment abatement and palliative care as ethically suspect. It is a Lear-like universe, where "Man is caught in a bewildering world of immediacies and appearances which make endurance and readiness more possible than understanding" (Peck 1967, 232).

On the other hand, the intimacy of nursing and other forms of health care and care-taking - that regular, close contact that recognizes and connects persons as beings with particular identities, bodies, and emotions, rather than the patient as "an external fact" or a "medical

\footnotetext{
$\overline{2}$ Jameton (2013) also has expanded his definition and application of moral distress in similar ways to other professions within and beyond health care. See this issue of the Journal of Bioethical Inquiry for his work on moral distress in relation to the environment and climate change.
} 
reading [that] must take him into account only to place him in parentheses" (Foucault 1994, 8) - is the basis of relational care (written about by Gilligan [1982], Held [1993], and Tronto [1994]; see also Lützén and EwaldsKvist [2013] and Peter and Liaschenko [2013] in this issue). Medical decision-making grounded in the parenthetical, that overrides the assessment of nurses and caretakers who have formed such bonds, gives rise to an unsurprising emotional response that has both a dialectical and an affective dimension.

The question "What are you?"-posed time and again in King Lear and related to that "nothingness" with which Lear and Edgar struggle - can be read as one that nurses and care-takers ask themselves when faced with morally distressing situations, in an attempt to do the right thing, overcome obstacles, and find a morally sound resolution to a dilemma. "What are you?" also can be read, however, as a condescending question posed by the powers-that-be, whether hospital administration, certain physicians, or an overall system that brackets patients and sees nurses and other care providers in less respected and thus less powerful positions.

A failure to hear, work through, and, where appropriate, act on the moral concerns of individual nurses or groups of nurses (often joined by other allied health workers) is also potentially detrimental to patient care. Moreover, it impoverishes institutional policy and procedure development and is even a threat to the vitality and functioning of corporate health care. Dare one say that it also is actually poor "risk management"?

It is thus crucial at every level of health care to make room for attending to outcries of moral distress, even if this "risks the emotional" in an otherwise "sterile" environment. At the same time, it is important to assist individual practitioners, again at all levels, with the means to lead examined lives and develop their own moral skills and boundaries, including with regard to the limits of their responsibilities. We are humans before we are professionals, and standards of practice and codes of conduct may be useful heuristics as long as they do not commandeer individual moral reflection. Psychodynamic forces (which may help or hinder) also can come into play, something that is sometimes poorly recognized by practitioners themselves or the teams in which they work. "Am I experiencing moral distress or my own (projected/transferred) distress?" is a question that does need answering. Practitioners cannot take on all of the perceived failings of the health system, nor is it healthy to do so.
"Speak[ing] what we feel," even perhaps before we have fully engaged in deliberation, when we "sense" something before we "know" it, can help with this. In fact, as Elizabeth Peter observes in her opening essay of this $J B I$ symposium on "Moral Distress" in relation to a paper by Kim Lützén and Béatrice Ewalds-Kvist (2013) that employs Viktor Frankl's existential philosophy, although "our moral sensitivity can give rise to moral distress when we are in situations in which we cannot enact our moral agency ... when we are able to experience meaning in these circumstances, moral distress can be limited" (Peter 2013, \6).

Thus, when it comes to bioethical issues, do we use an objective, dispassionate stance where we (think we) leave aside our messy humanity or do we proceed as total but flawed beings, using all of our senses and emotions? There is a strong thread in modern bioethics of unreconstructed logical positivism, of cold hard logic and objective empiricism, particularly in the utilitarian camp. Some have gone so far as to say that bioethics is no subject at all because it lacks rigor and method and by implication lets in too many unruly, "unscientific" emotions. But we cannot switch ourselves off as Rawls, for instance, would have us do and approach the question of "What are you?" and, thus, "What is right?" behind his veil. We are not robots, nor would we want to be. (In fact, we tend to focus on the opposite, imbuing robots with a "longing" for human consciousness.) But just when Western society began realizing this, as the Romantics struggled with the concept of pure reason, and ultimately rejected it, science came along and took its place as an external technique for moral discernment.

We do not wish to throw out the reasoning baby with the bathwater but instead, perhaps, gaze upon the fuller family portrait, to recognize that there are more beings than baby in the bathroom.

It is a curious development in health care, as it is in theories of moral development, as philosopher Virginia Held (1990) notes, that "mothering" is either denigrated or all but nonexistent. While those men capable of reason that have been described by many moral philosophers seem already "fully formed" (Held 2002, 56) and "sprung out of the earth ... like mushrooms" (Hobbes cited by Held 2002, 56), the history of human life makes clear (particularly with the advent of walking upright and the greater maternal mortality that comes with it) that "a body politic" cannot consist "of orphans who have reared themselves" 
(political scientist Christine DiStefano cited in Held 2002, 56). Likewise, the central tenets of D. W. (Donald) Winnicott (1986) of "holding" (i.e., taking on or helping another to manage physical, emotional, intellectual aspects of life until he or she is able to do so) and the "good enough" mother (i.e., gradually but increasingly relinquishing control as the capacity of the other grows) as nurturing and supportive understandings need to permeate the hurly-burly of clinical life in our modern hospitals.

Making room for what has been associated with the "feminine" will actually make us better providers and leaders than a reliance on reason alone. This is how Edgar in King Lear not only comes to be heir apparent to the kingdom but also discovers his own identity, out of nothingness and finally free from all disguise (Peck 1967). As Peck writes, the "miracle which is born from misery finds nurture in kind acts," as when Edgar cares for (in the actual and affective senses of the term) both his father and Lear $(1967,230)$. Seen in this light, the play "movingly dramatizes the response and responsibility of one being for another" and "asserts a fundamental human kinship which goes even deeper than familial ties" (Peck 1967, 235 and 231, respectively). "Edgar's actions in the play," Peck believes, "are part of an effort to approach the humanistic questions of man's identity and meaning in the universe. As such they serve as a foil to Lear's self-searching" (1967, 220).

Are we then really capable (and do we want to be) of stepping back like kings (note the gender here!) and doing a Socratic "on the one hand and on the other" neutral analysis of bioethical issues without the intrusion of the ego and the emotions, of religious belief, society, politics, gender, and race?

When it comes to resolving the great mysteries of life, reason alone is insufficient, as another Edgar-19thcentury American writer and poet Edgar Allan Poe- emphasized in his "Tales of Ratiocination." Poe's conception of ratiocination is a combination of analysis and imagination, or reason and feeling, and potentially offers fertile ground for overcoming the dichotomous male/female, public/private, rational/emotional ideas rooted in Western history and philosophy (Rich 2011). Writing in the mid-1800s, Poe fashioned this ratiocination and his great detective, Auguste Dupin, during the late Romantic and early Victorian eras, a time period that not only followed the Age of Enlightenment and its elevation of reason and emphasis on method but also the gritty and graphic realities of the Industrial Revolution. Romanticism, although it did not wholly refuse the legacy Enlightenment had bequeathed, responded to both by positioning imagination "as the supreme faculty of the mind" (Brooklyn College English Department 2009 , 94). Dupin, who is introduced in the 1841 story "The Murders in the Rue Morgue" and becomes the archetype for all subsequent super sleuths to this day, possesses a "Bi-Part Soul" that necessarily relies on both "the creative and the resolvent" (Poe 1989, 10).

In this broader picture, strong feelings that result from a sense of unfairness and injustice, especially if experienced by a clinician in a therapeutic relationship with a client who, it is felt, is being wronged, clearly have their place. Albert Camus talks of the need for acts of rebellion by "l'homme revolte," the only sane reaction to an absurd world. Perhaps Camus would see moral distress as a form of "revolt" in a health care system where the individual as full human being still gets lost and decisions seem to be constructed by professional and corporate agendas that too easily base themselves on false perceptions of what law and ethics really require, especially as death approaches.

As philosopher Ernst Cassirer wrote in 1944 (a year before his death): "Science gives us order in thoughts; morality gives us order in actions; art gives us order in the apprehension of visible, tangible, and audible appearances" (cited in Merriam 1964, 230). And all must be taken together. We do not discover the essence of beauty - whether in paintings, scientific discovery, or the good-by merely breaking it open, taking it to bits, and leaving it as that. Rather, it is a matter of applying multidimensional study of situations and systems, of looking and knowing and feeling in different ways, of using different tools that the best understanding is gained. This is why the Journal of Bioethical Inquiry favors multidisciplinary investigation and introspection and engaging with subjects and attending to the same issue or phenomenon as not just mindful but embodied beings. This is our, and bioethics', "chief end ... to set off the growth of ... insights into the human condition" and, like the philosopher Edgar, to "learn[] a great deal about human nature and human suffering" (Peck 1967, 223 and 225).

The symposium on "Moral Distress" in this issue of the $J B I$ proposes to do just that and help each of us in our own interconnected pilgrimages to learn to "act[] with a 'royal nobleness" and "towards a reknowing of [ourselves] in all [our] identities” (Peck 1967, 233 and 234). 


\section{References}

Brooklyn College English Department. (2009). Romanticism. Adapted from $A$ guide to the study of literature: A companion text for Core Studies 6, Landmarks of Literature. http://academic.brooklyn.cuny.edu/english/melani/cs6/ rom.html. Accessed 20 March 2011.

Edwards, M., S. McClement, and L. Read. 2013. Nurses' responses to initial moral distress in long-term care. Journal of Bioethical Inquiry 10(3). doi:10.1007/s11673-013-9463-6.

Foucault, M. 1994. The birth of the clinic: An archaeology of medical perception, trans. A.M. Sheridan Smith. New York: Vintage Books. Originally published as Naissance de la clinique (Paris: Presses Universitaires de France, 1963).

Gilligan, C. 1982. In a different voice: Psychological theory and women's development. Cambridge: Harvard University Press.

Held, V. 1990. Feminist transformations of moral theory. Philosophy and Phenomenological Research 50(suppl): 321-344.

Held, V. 1993. Feminist morality: Transforming culture, society, and politics. Chicago: University of Chicago Press.

Held, V. 2002. Feminist transformations of moral theory. In Morality and moral controversies: Readings in moral, social, and political philosophy, 6th ed, ed. J. Arthur, 5359. Upper Saddle River, NJ: Prentice-Hall.

Jameton, A. 1984. Nursing practice: The ethical issues. Englewood Cliffs, NJ: Prentice-Hall.

Jameton, A. 2013. A reflection of moral distress in nursing together with a current application of the concept. Journal of Bioethical Inquiry 10(3). doi:10.1007/s11673013-9466-3.
Lützén, K., and B. Ewalds-Kvist. 2013. Moral distress and its interconnection with moral sensitivity and moral resilience: Viewed from the philosophy of Viktor E. Frankl. Journal of Bioethical Inquiry 10(3). doi:10.1007/s11673-013-9469-0.

McCarthy, J., and R. Deady. 2008. Moral distress reconsidered. Nursing Ethics 15(2): 254-262.

Merriam, A.P. 1964. The anthropology of music. Evanston, IL: Northwestern University Press.

Peck, R.A. 1967. Edgar's pilgrimage: High comedy in King Lear. Studies in English Literature 7(2): 219-237.

Peter, E. 2013. Advancing the Concept of Moral Distress. Journal of Bioethical Inquiry 10(3). doi:10.1007/s11673013-9471-6.

Peter, E., and J. Liaschenko. 2013. Moral distress reexamined: A feminist interpretation of nurses' identities, relationships, and responsibilities. Journal of Bioethical Inquiry 10(3). doi:10.1007/s11673-013-9456-5.

Poe, E.A. 1989. The murders in the Rue Morgue. In Ten great mysteries by Edgar Allan Poe, ed. G. Conklin, 3-49. New York: Scholastic, Inc.

Rich, L.E. 2011. Supervisor but no "super genius": Gender, race, and ratiocination in American television. Paper presented at the annual meeting for the Southeastern Women's Studies Association, March 24-26, in Atlanta, Georgia.

Tronto, J. 1994. Moral boundaries: A political argument for an ethic of care. New York: Routledge.

Winnicott, D.W. 1986. Home is where we start from: Essays by a psychoanalyst. London: Penguin.

World Health Organization. 1946. Constitution of the World Health Organization. http://whqlibdoc.who.int/hist/ official records/constitution.pdf. 